\title{
Relationship between Workers' Remittances and Money Supply from 2000 to 2018: Using the Vector Autoregression Model
}

\author{
Ateyah Mohammad Alawneh ${ }^{1}$ \\ ${ }^{1}$ Tafila Technical University, College of Business, AT-Tafila, Jordan \\ Correspondence: Dr. Ateyah Mohammad Alawneh, Tafila Technical University, College of Business, AT-Tafila, \\ Jordan. E-mail: ateayh1@yahoo.com
}

Received: December 21, 2019

Accepted: January 12, 2019

Online Published: January 16, 2020

doi:10.5539/ijbm.v15n2p92

URL: https://doi.org/10.5539/ijbm.v15n2p92

\begin{abstract}
This study aims to analyze the quality and nature of the relationship between workers' remittances and money supply (M2) in Jordan from 2000 to 2018. The descriptive approach and standard statistical analysis method are employed to construct and analyze the model using Eviews. The results of the unit root test reveal the stability of the current study's variables at the second difference. Granger causality test indicates that a causal relationship exists between workers' remittances and M2 of workers' remittances. The analysis of variance regarding the importance of workers' remittances in the interpretation of M2 confirms the positive impact of workers' remittances on M2. The results of the two variables are also integrated, thereby yielding at least one integration between the two variables at the level of statistical significance.

Contribution/ Originality: This study will be one of the few to examine workers 'remittances and their impact on money supply in developing countries, especially in Jordan, which rely heavily on workers' remittances. The study also provides a scientific addition in the field of financial and economic sciences from a scientific point of view through the use of different statistical methods and from a practical point of view for planning future monetary and financial policies as well as making monetary and financial decisions in the country. Also, the study helps decision makers in developing the financial and banking sector in the country.
\end{abstract}

Keywords: International cash flows, international financing, money supply, workers 'remittances

\section{Introduction}

Workers' remittances gain considerable attention from researchers given that their remittances constitute an important part of the cash flows that affect the overall economy, particularly in developing countries. However, Jordan has suffered from a steady decline of remittances from overseas workers, thereby affecting money supply (M2) and economic activity. Workers' remittances are an important outflow in Jordan that reflect the M2. Remittance from overseas workers affects M2 by the circulation of various kinds of cash and deposits among the banks in Jordan. The labor force in the Gulf States is also affected by economic conditions, including Jordanian labor.

Furthermore, the increase in M2 increases the economic activity in the country that receive remittances from workers. The reciprocal relationship between workers 'remittances and the money supply, as the increase in workers' remittances leads to an increase in money supply in Jordan, and consequently an increase in economic activity, which leads to economic stability and consequently an increase in more influx of workers 'remittances from the Arab Gulf states in addition to the economic relationship and economic interdependence between Jordan And the Arab Gulf states. But the problem of Workers' remittances is affected by the economic situation in neighboring countries It decreased by $1.3 \%$ from 2009 to 2010 (Jordan Ministry of Planning and International Cooperation).

This study seeks to clarify the relationship between overseas workers' remittances and M2 in Jordan in general. In particular, this study investigates whether a relationship is present between overseas workers' remittances and M2 in Jordan and determines the appropriate methods to predict this relationship. The importance of the study is presented in two aspects, namely, scientific and practical significance. This study is scientifically significant by shedding light on the limit of important topics and few studies to the -knowledge of the researcher-, which have not been addressed at the level of Jordan. A model that shows the relationship between overseas workers' remittances 
and M2 in general is developed given that the relationship between remittances and M2 is vague. Thus, this study is beneficial by determining the nature and direction of the relationship between workers 'remittances and M2, thereby helping researchers to understand the behavior of each variable. In addition, this study is valuable for decision makers of monetary policy by allowing them to determine the relationship between workers' remittances and M2. Workers' remittances and M2 are significant for increasing economic activity and economic growth through their impact on the economic investment covered by the state to offset the deficit in the public budget and the deficit in the balance of payments, unemployment, and poverty.

\subsection{Problem of the Study}

Accordingly, problem statement of the current study Given that Jordan has recently faced a decline in remittances from its workers that affected the M2 and thus economic activity, Also, replacing foreign labor with local labor in the Arab Gulf states will lead to an impact on the remittances of Jordanian workers and consequently economic imbalances in Jordan, including a decrease in the flow of overseas workers' remittances to Jordan and the occurrence of economic imbalances, including a decrease in the money supply, For this a model predicting the causal relationship between these variables should be identified to answer the following questions. Is there a causal relationship between remittances and M2 from one side or two side? Does M2 affect overseas workers' remittances?

\subsection{Hypothesis of the Study}

Based on the above analysis, the researcher stated following hypothesis of the study

A statistically positive and significant relationship exists between workers' remittances and M2 in general. A statistically significant causal relationship is evident between workers' remittances and M2 in general.

\subsection{Objective of the Study}

The objective of the study to derive a standard model by using the modern time series analysis method using vector autoregression (VAR) models to discover the nature and direction of the relationship between overseas workers' remittances and M2 in general. Moreover, this paper intends to measure the potential reaction between the study variables and the response to random shocks and describe the dynamic and motor behavior of workers' remittances and the broad presentation of criticism. The negative relationship between overseas remittances and M2 is analyzed, and the development of remittances and M2 in Jordan during the study period is clarified.

\section{Previous Studies}

Numerous previous studies that have focused on workers' remittances and their relationship to economic growth are available.

A study of Suwastika Naidu, Atishwar Pandaram and Anand Chand (2017), Where the study was based on research on the relationship between workers' remittances issued from Japan on economic growth (outflow of cash flows) using the Granger causality test, where the analysis showed that there is a negative relationship of workers remittances issued on economic growth in Japan in the long term and short term because the flow of money (cash) From Japan to neighboring countries leads to a reduction in the rate of economic growth in Japan.

Study of Naoyuki Yoshino, Farhad Taghizadeh-Hesary, and Miyu Otsuka (2019), where the study indicates that the flow of remittances to middle-income countries helps to increase investments and encourage economic growth, and also indicates that the flow of more transfers to countries with political stability and thus an increase in the money supply that leads to more growth.

Mashayekh (2013) focused on the contribution of remittances toward economic development and poverty reduction and their significant contributions to poverty reduction and infrastructure. Notably, the study recommended that the state should provide incentives and improve immigration policies for the flow of additional remittances. While Ahmed, Zaman, and others (2011) showed the effect of workers' remittances and exports and the offer of rich money on the economic growth in Pakistan. Results revealed that workers' remittances and exports are important for influencing economic growth in the short and long terms, whereas M2 fails to exhibit a significant impact on growth. In this context Masuduzzaman (2014) investigated the mutual integration of workers' remittances and economic growth. Their study used the analysis of Johansson and the analysis of causality, thereby finding a long-term relationship between workers' remittances and economic growth. This relationship contributes to the activation of economic policies in the country. Khodeir (2015) verified the impact of workers' remittances in Egypt and found that workers' remittances exhibit an impact on per capita income, thereby affecting the M2, oil prices, and investment. Thus, workers' remittances affect investment and not family income. This finding provides significant implication to the local economic policy. while Roy and Rahman (2014) 
conducted an analysis through co-integration to determine the long-term relationship between workers' remittances and inflation. Their study unveiled that workers' remittances increase the M2 that leads to inflationary pressures. Accordingly, inflationary pressures in the country affect prices of commodities. Taghavi (2012) aimed to study the causal relationship between remittances and economic growth in the Gulf Cooperation Council. Their study focused on certain macro indicators (real GDP, real M2, real interest rates, real effective exchange, and real transfers). The causal analysis on the disruption of remittances revealed that the Gulf Cooperation Council's macroeconomic indicators are weak to limit the flow of remittances. In addition, results indicated that remittance flows from the Gulf Cooperation Council exhibit a positive impact on its growth. Also, study of S. Imai, Malaeb, and Bresciani (2017) clarified the role of workers' remittances in promoting growth and reducing poverty in Asia and the Pacific. They found that remittances promote economic growth and reduce poverty.

Certain studies on M2 and several other variables are also available. For instance, E. Adenutsi and Ahortor (2008) discussed the relationship between remittance flows on M2, interest rate, exchange rate, and local price level by using the VAR model. Results indicated that a positive relationship exists among M2, exchange rate, interest rate, and money transfers, whereas local price is negatively affected, the study also found through the analysis of response functions, that workers 'remittances respond to workers' remittances, not M2.

Akinbobola (2012) analyzed M2, exchange rate, and inflation in Nigeria. The quantitative analysis vector error correction model (VECM) confirmed that M2 has a negative impact on inflation in the long term, while economic growth and exchange rate changes affect inflation. A study of Uzoh Akuony ben, Nwachukwu Atanasius and Uzoma Kelechi p (2019) found a positive relationship between workers 'remittances and the development of the financial sector in Nigeria. The study also indicates that workers' remittances have a role in developing financial and banking markets and attracting more money through financial and monetary institutions that lead to growth and development.

Niaz Hussain Ghumro and Mohd Zaini Abd Karim.(2017), The results of the study showed that remittances of workers have a positive impact on money supply in Pakistan, especially $\mathrm{m} 1$.

Mohamed, Zahran(2019)the study analyzed the response of workers 'remittances to Egypt to oil price shocks, the study found that the increase in workers' remittances is positive for oil price shocks, and that workers 'remittances decrease in response to lower oil prices.

This study investigates the relationship between workers' remittances and M2 in general by using the VAR model. Apart from the study of Deodat E. Adenutsi, study of Niaz Hussain Ghumro and Mohd Zaini Abd Karim.(2017) and Christian RK Ahortor (2008) that dealt with the relationship between workers' remittances and money supply, as well as the study of T.O. Akinbobola (2012), the majority of the previous studies focused on the relationship between workers' remittances and economic growth. Moreover, the statistical methods used in the current study, such as the VAR model and the investigation of the causal relationship between the aforementioned variables, are not used by the previous studies.

\section{Theoretical Framework}

\subsection{Volume of Evolved Workers' Remittances and M2 during the Study Period}

\subsubsection{Descriptive Statistics of Study Variables}

The descriptive statistics of study variables are determined prior to data analysis. Subsequently, the study variables' historical development of time series and trends during the study period are also analyzed.

Table 1. Illustrates the descriptive analysis of variables during the study period (2000-2018)

\begin{tabular}{lcccc}
\hline variables & minimum & highest value & Average & standard deviation \\
\hline RMT & 1177.300 & 2423.300 & 1970.774 & 445.1732 \\
M2 & 33359.30 & 7434.700 & 20154.11 & 9389.811 \\
\hline
\end{tabular}

Source: E-views program dependent on appendix (1).

Table 1 indicates that the highest value of the workers' remittances (RMT) amounted to JD 2,423.300 million in 2015, whereas its lowest value was estimated at JD 1,177,300 million in 2000. M2 in general (M2)'s highest value was JD 7434.700 million in 2000, whereas its lowest value was JD 33359.30 in 2018. Therefore, the M2 increased by more than $22 \%$ during the study period and witnessed a steady growth from 2000 to 2018 . 


\subsubsection{Stages of Development of Study Variables}

Figure 1 illustrates the historical path of the volume of remittances in Jordan during the study period, which can be divided into two main periods. The first period was 2000to2018 that witnessed a clear increase in the volume of workers' remittances, while several fluctuations occurred. In 2001, the total remittances of workers amounted to 1,117 million dinars, which continued to rise until it reached at 2,242 million dinars in 2009. The second period starts from 2010 to 2017 that was characterized by clear fluctuations. During this period, the remittances increased and decreased slightly due to the economic conditions in the Gulf countries, particularly in the recent years due to the decline in oil prices. Consequently, the demand for Jordanian labor also decreased.

RMT

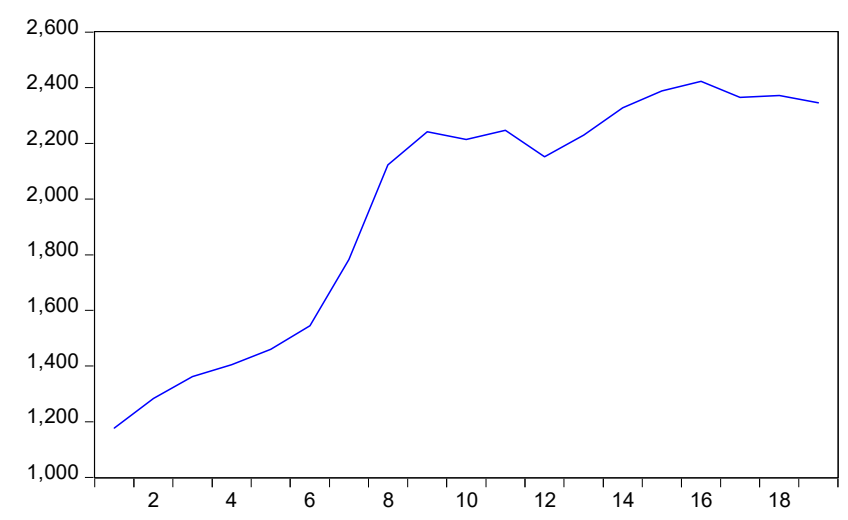

Figure 1. Evolution of remittances during the study period

Source: E-views program dependent on appendix (1).

Figure 2 demonstrates that the series of evolution of the M2 volume takes positive trends each year during the study period. Notably, Figures 1 and 2 concludes that both periods contain a general direction vehicle, which suggests that they are initially unstable. Therefore, the findings are subject to stability testing.

M2

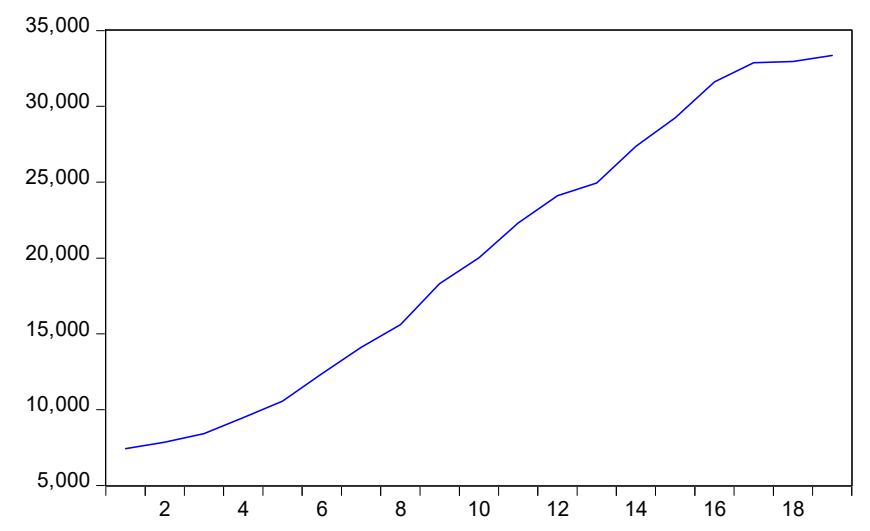

Figure 2. Evolution of M2 during the study period

Source: E-views program dependent on appendix (1).

\subsection{Relationship between Workers' Remittances and Money Supply}

The IMF reports that the World Bank has estimated official cross-border remittances of $\$ 88.1$ billion in 2002 and $\$ 93$ billion in 2003. Latin American and the Caribbean regions received the highest amount of international remittances at 30\%, followed by South Asia at 18\%, the Middle East and North Africa at 13\%, Europe and Central Asia at 10\%, and Sub-Saharan Africa at 4\%. Mexico is the top recipient of international remittances, while the United States and Saudi Arabia are the main senders of remittances. Remittances are defined as 
transfers between businesses, such as payment of bills and flows of funds; transfers from businesses to individuals, including salaries; and transfers of funds from governments to individuals, including pension and social benefits. Remittances between institutions are higher than transfers from one person to another, but remittances between individuals are the most important types of remittances for the poverty-stricken families. (Jennifer \& Iserne, 2005).

The flow of remittances may intensify the money supply that fuels demand for services and goods, and boost the pattern of service spending the goods. Escalating demand puts increasing pressure on prices that increase Demand contributes to inflation (Saghir, Pervaiz, \& Ghauri, 2019). In addition, many studies indicate that workers' remittances have a role in influencing inflation by affecting money supply and increasing demand for goods and services in the economy. (Javed,Iqbal and other 2013) In this context, some studies also show a positive relationship between workers' remittances and money supply (Niaz, Hussain, Ghumro \& Mohd, Zaini Abd Karim, 2017). In addition, workers' remittances provide families and the state with the necessary funds, which are better than loans, especially at an abnormal time. (The International Fund for Agricultural Development, 2015). Also, some studies show workers' remittances increase the money supply of families through remittances from workers abroad, which increases their purchasing power. (Friday, 2019). Workers' remittances are important to support the Jordanian economy in foreign currencies. Most of them undergoes the banking system where people open various kinds of bank accounts in the operating banks. Given that demand deposits, futures, and savings are components of $\mathrm{M} 2$, increasing the flow of remittances thus increase deposits at the bank. Consequently, M2 also increases.

The majority of previous studies, such as those of Mina Mashayekh (2013), of Junaid Ahmed, Khalid Zaman, and Iqtidar Ali Shah (2011), of Mahedi Masuduzzaman (2014), of Ripon Roy and Md. Mokhlesur Rahman (2014), and of Katsushi S. Imai, Bilal Malaeb, and Fabrizio Bresciani (2017), revealed that remittances increase investment and economic growth. The reciprocal relationship between workers' remittances and M2 is derived from the nature of the Jordanian economy that is interconnected with the economy of the Arab Gulf countries. Thus, the growth of real investment in Jordan tends to increase workers' remittances, which directly reflects the improved growth in Jordan (http://alrai.com/article/128645.html). This growth is expected to improve economic conditions in neighboring countries. For instance, improving the Jordanian economy should be reflected by the improvement of the economic situation among the Gulf countries, this is because of the mutual relationship and economic interlock between them. In particular, the economic improvement across the Gulf countries increases the demand for Jordanian labor and thus increases the flow of remittances from the Jordanian labor abroad. Many previous studies also refer to this for example study of Suwastika Naidu, Atishwar Pandaram and Anand Chand (2017) study of Naoyuki Yoshino, Farhad Taghizadeh-Hesary, and Miyu Otsuka(2019) also study of Uzoh Akuony ben, Nwachukwu Atanasius c and Uzoma Kelechi p (2019).

Then the above Workers' remittances affect money supply and may lead to inflation. Where the central bank can use non-conventional tools to absorb liquidity and reduce the impact of workers' remittances on inflation, such as Islamic Sukuk It also highlights its importance to central banks by using them to absorb liquidity and reduce inflation rates. Because, it is issued off-budget and at low cost (Nawal, Ben Amara, 2011).

\section{Methodology of the Study}

This study uses descriptive analysis by searching for secondary sources from Central Bank bulletins to obtain data and concepts related to workers' remittances and M2.

The construction of the VAR model requires the analysis of time series stability through the Dickey-Fuller test to determine the number of time slots in the model and investigate the causal relationship between the study variables where the practical aspect of the study depends on the following statistical analyses.

-Degree of stability: through the Dickey-Fuller test to determine the number of time slots in the mode.

-Deceleration of study variables to determine the number of time lags.

\section{-Estimation of VAR mode}

-Analysis of the causal relationship between the study variables

-Response Functions: the immediate response function is concerned with measuring the potential reaction of a variable.

-Analysis of variance: The analysis of variance focuses on highlighting the relative importance of the constituent variables of the model 3 .

-Co-integration: through Johnson co-integration test where aims to test the equilibrium relationship in the long 
term.

\section{-Definition of study variables}

MTR: Overseas workers' remittances

M2: Money supply in the broad sense

\section{Applied Side of the Study}

\subsection{Identifying the Degree of Stability}

Time series are often characterized by medium instability and variation as a result of growth and change over time. Stability testing is conducted to examine the characteristics of time series and to ensure stability and degree of integration prior to using them in statistical analysis. This test prevents false and misleading results that fail to reflect the reality. The time series in the tests should be stable at one degree, and the stability test is performed through the Dickey-Fuller test statistic.

Table 2 shows that the study variables lack stability at the required level. All the calculated absolute values of the Dickey-Fuller test are less than the critical values at the 5\% and 1\% levels. Accordingly, the test is repeated at the first difference.

Table 2. Unit root test results for study variables at level

\begin{tabular}{llcl}
\hline variable & Calculated value & possibility & the decision \\
\hline RMT & 0.052782 & 0.9520 & unstable \\
M2 & -1.678370 & 0.4236 & unstable \\
\hline
\end{tabular}

Source: E-views program dependent on appendix (1).

Table 3 shows that the study variables are unstable at the first degree, while all the calculated absolute values of the Dickey-Fuller test are less than the critical values at the 5\% and 1\% levels. Accordingly, the test is conducted at the second difference.

Table 3. Results of unit root test for study variables at first difference

\begin{tabular}{llll}
\hline variable & Calculated value & possibility & the decision \\
\hline RMT & -2.470099 & 0.1393 & unstable \\
M2 & -2.163275 & 0.2251 & unstable \\
\hline
\end{tabular}

Source: E-views program dependent on appendix (1).

Table 4 displays that the study variables settle at the second difference, while all the calculated absolute values of the Dickey-Fuller test are greater than the critical values at the 5\% and $1 \%$ levels. Thus, the study variables are stable and integrated in the second degree.

Table 4. Results of unit root test for study variables at second difference

\begin{tabular}{llll}
\hline variable & Calculated value & possibility & the decision \\
\hline RMT & -5.621031 & 0.0004 & stable \\
M2 & -3.976347 & 0.0090 & stable \\
\hline
\end{tabular}

Source: E-views program dependent on appendix (1).

\subsection{Deceleration of Study Variables}

Table 6 indicates the criteria used to determine the number of time lags. In addition, Table 6 reports that the lowest value of the degree of slowdown based on the five-test criteria, such as LogL, LR, FPE, AIC, SC, and HQ, is achieved at time interval 1. Thus, causality at time (1) lag and VAR test for model M2 and MRT at time (1) lag are tested. 
Table 5. Determining the optimal lag for model variables

\begin{tabular}{lllllll}
\hline Lag & LogL & LR & FPE & AIC & SC & HQ \\
\hline 0 & -306.6682 & NA & $2.69 \mathrm{e}+12$ & 34.29647 & 34.39540 & 34.31011 \\
1 & -242.9643 & $106.1731^{*}$ & $3.56 \mathrm{e}+09^{*}$ & $27.66270^{*}$ & $27.95949^{*}$ & $27.70363^{*}$ \\
\hline
\end{tabular}

Source: E-views program dependent on appendix (1).

\subsection{Estimation of VAR Model among the Study's Variables}

Table 7 illustrates the results of the model of workers' remittances and indicates that the model exhibits a statistical significance. The calculated value of $\mathrm{F}$ is 151.7166 , which is greater than its tabular counterpart. The value of the coefficient of determination is $95.28 \%$. That is, $95.28 \%$ of the changes in workers' remittances are explained by the variables included in the form.

A positive relationship is found between workers' remittances in the previous year and workers' remittances in the current year. However, a negative effect of the previous year's M2 is evident on the workers' remittances during this year.

Based on Table 7, the M2 model is statistically significant. Therefore, the value of calculated 2,263.333, which is greater than its tabular counterpart. Notably, Table 6 indicates that the explanatory value of the model reached $99 \%$. A positive effect of workers' remittances last year was evident on the M2, thereby resulting in the positive effect on the M2 this year.

The stability of the VAR model can also be confirmed by converting the model in the figure form. Diagram (3) unveils the points within the unitary circle, which shows that the chains are stable

Table 6. Estimation of var model for variables

\begin{tabular}{lc}
\hline Vector Autoregression Estimates & \\
M2 & RMT \\
\hline 3.263355 & 0.978259 RMT(-1) \\
$(0.77948)$ & $(0.13327)$ \\
{$[4.18657]$} & {$[7.34048]$} \\
0.852611 & -0.004253 M2(-1) \\
$(0.03848)$ & $(0.00658)$ \\
{$[22.1579]$} & {$[-0.64646]$} \\
-2060.737 & 189.8976 C \\
$(889.821)$ & $(152.134)$ \\
{$[-2.31590]$} & {$[1.24823]$} \\
0.996697 & 0.952894 R-squared \\
0.996257 & 0.946614 Adj. R-squared \\
4677564. & 136731.0 Sum sq. resids \\
558.4242 & 95.47462 S.E. equation \\
2263.333 & 151.7166 F-statistic \\
\hline
\end{tabular}

Source: E-views program dependent on appendix (5). 


\section{Inverse Roots of AR Characteristic Polynomial}

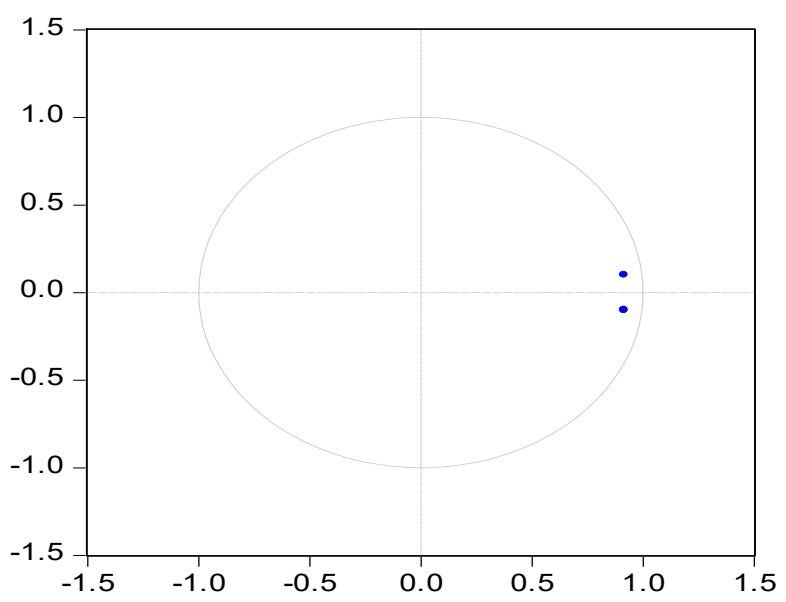

Figure 3. VAR model in graph form

Source: E-views program dependent on appendix (1).

\subsection{Analysis of the Causal Relationship between the Study Variables}

Table 10 uncovers that the variable overseas workers' remittances affects M2 with a time gap at 5\%. Therefore, the hypothesis that a causal relationship exists between overseas workers' remittances and M2 in general at 5\% significance level is validated. By contrast, M2 fails to influence workers' remittances at the 5\% significance level. Accordingly, the hypothesis that a causal relationship between M2 and workers' remittances at a significance level of $5 \%$ is rejected.

Table 7. Causal relationship between study variables (M2) and (RMT)

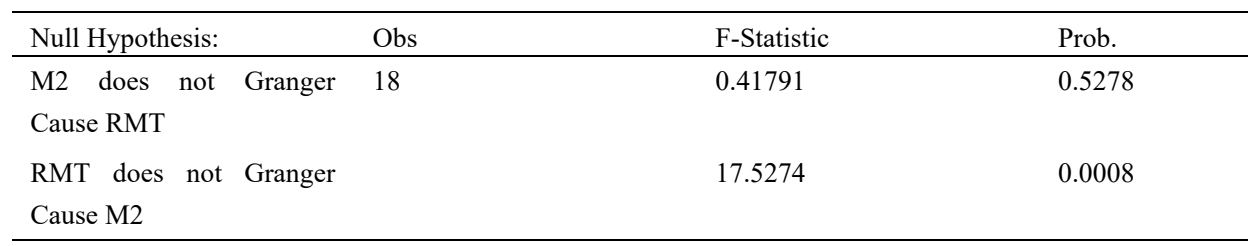

Source: E-views program dependent on appendix (1).

\subsection{Response Functions}

The immediate response function is concerned with measuring the potential reaction of a variable that is caused by a sudden random shock in one of the other variables of the model. In particular, the immediate response function measures the impact of that shock on the present and future value of other variables (The krep Allah, 2018).

The immediate response function measures the future effect of a variable's response to itself and to all the variables included in the model, which is the result of a sudden random shock of one standard deviation in one variable. Figure 4 displays that the amount of positive random shock in workers' remittances exhibits a negative impact on workers' remittances from the 1 st year to the 10th year. Therefore, overseas workers' remittances this year have a negative impact on workers' remittances during the study period.

Figure 4 reveals that the positive random shock of one standard deviation in M2 fails to affect workers' remittances until the end of the $1^{\text {st }}$ year. This effect slightly and negatively continues until the end of the $10^{\text {th }}$ year. Therefore, the future movements of M2 in general over time exhibits a slight negative impact on the volume of overseas workers' remittances during the study period.

Figure 4 illustrates that the amount of positive random shock in the M2 has a consistent negative impact on M2 in general until the 10th year. Therefore, the future movements of M2 over time exhibits a negative impact on M2 in general during the study period.

Figure 4 reveals that a positive random shock of one standard deviation in overseas workers' remittances exhibits a 
positive effect on M2 in general, which is consistent until the end of the $10^{\text {th }}$ year during the study period. Therefore, the future movements of workers' remittances over time have a positive impact on M 2 during the study period.

Based on the analysis above, the results obtained through the application of the immediate response interaction function, particularly with regard to the interaction between remittances and the M2, signifies that a statistically significant and positive effect of overseas workers' remittances on M2 is evident, whereas no statistically significant effect of M2 is found on workers remittances.

The response functions' results confirm the hypothesis that a positive and statistically significant relationship exists between workers' remittances and M2.
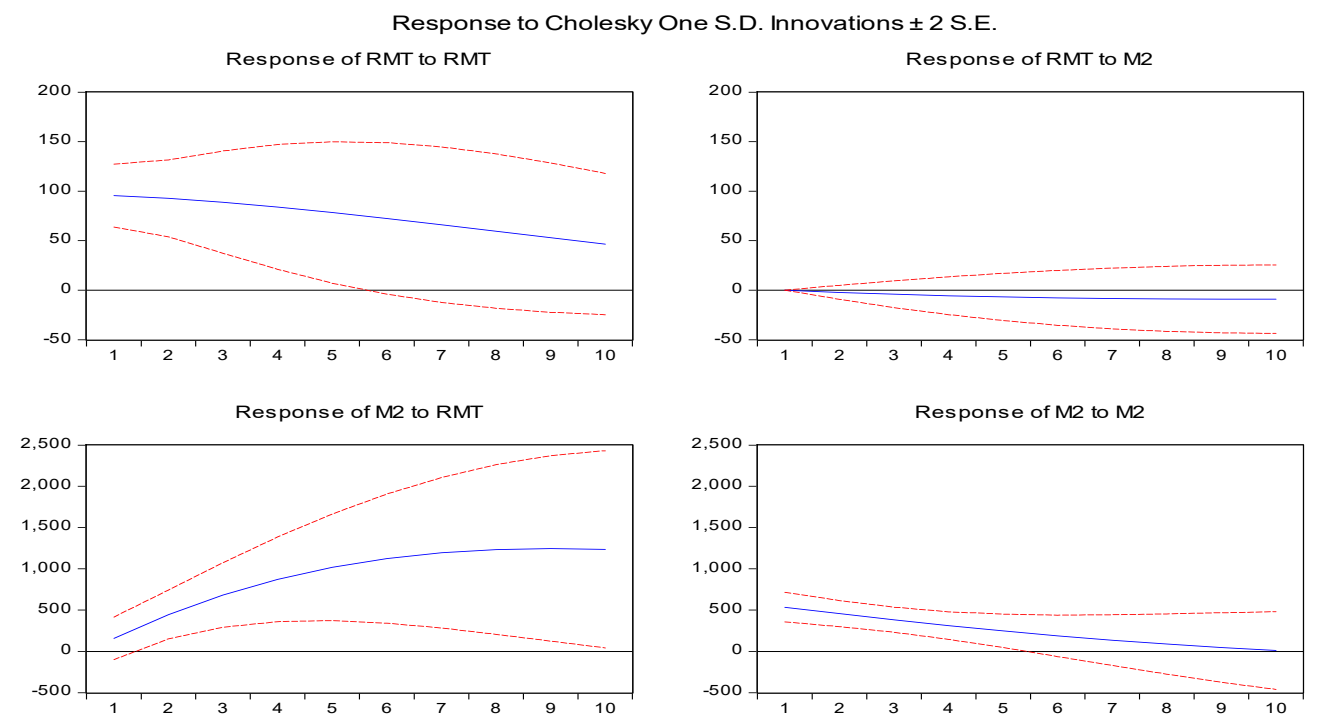

Form 4. Response functions to study variables

Source: E-views program dependent on appendix (5).

\subsection{Analysis of Variance}

The analysis of variance focuses on highlighting the relative importance of the constituent variables of the model. This test is beneficial for discovering the variance in the prediction of the variable, which is attributed to the prediction error in the same variables and the rest of other variables.

The analysis of variance component is one of the methods of describing the kinetic behavior of model variables.

The variability of the prediction error for a variable is due to the unforeseen shocks for each of the variable demonstrated during the prediction period. (Krep Allah, 2018).

Table (8) reveals the results of variance components for each of the variables of the study, which is due to the error of variance in the same variable and other variables. If overseas workers' remittances interpret $100 \%$ of the prediction error in the variance attributed to the same variable during the 1st period and the 7th period, then the ratio decreases to $99.51 \%$ compared with $0.48 \%$ for those attributed to the M2 variable.

This percentage subsequently increases to reach the limits of $0.82 \%$ in the 10 th period compared with about $99.17 \%$ due to the variable overseas workers' remittances.

Table (8) reveals that the amount of prediction in the variation of overseas workers' remittances attributable to the same variable tends to decrease slightly over time. The line of prediction increases because the M2 variable indicates that minimal importance is toward the M2 for explaining the behavior of overseas' workers remittances in the current period through time movements. 
Table 8. Variance decomposition of RMT

\begin{tabular}{cccc}
\hline Period & S.E. & RMT & M2 \\
\hline 1 & 95.47462 & 100.0000 & 0.000000 \\
2 & 133.1134 & 99.97070 & 0.029295 \\
3 & 160.0776 & 99.91184 & 0.088160 \\
4 & 180.8596 & 99.83143 & 0.168575 \\
5 & 197.2607 & 99.73564 & 0.264363 \\
6 & 210.2772 & 99.62938 & 0.370623 \\
7 & 220.5714 & 99.51667 & 0.483335 \\
8 & 228.6382 & 99.40089 & 0.599109 \\
9 & 234.8745 & 99.28497 & 0.715028 \\
10 & 239.6127 & 99.17144 & 0.828556 \\
\hline
\end{tabular}

Source: E-views program dependent on appendix (1).

With regard to the analysis of the variance components attributed to the M2 variable, Table (9) indicates that the M2 variable in general explains roughly $92.03 \%$ of the variance error attributed to the same variable during the $1^{\text {st }}$ period versus $7.96 \%$ of the variance error is explained by the overseas workers' remittances for the same period. Moreover, the percentage in the $7^{\text {th }}$ period decreases to $14.16 \%$ compared with $85.83 \%$ for those attributed to overseas workers' remittances. Subsequently, this percentage decreases to reach $8.11 \%$ in the $10^{\text {th }}$ period compared with $91.88 \%$ due to the RMT. Table (9) reveals that the amount of prediction in the variation of M2 due to M2 tends to decrease over time. By contrast, the prediction line increases because of workers' remittances. Thus, the strong relative importance of the workers' remittances is evident in the interpretation of M2 behavior in the current period through time movements.

Table 9. Variance decomposition of M2

\begin{tabular}{llll}
\hline Period & S.E. & RMT & M2 \\
\hline 1 & 558.4242 & 7.967997 & 92.03200 \\
2 & 848.1441 & 31.10199 & 68.89801 \\
3 & 1153.925 & 51.81976 & 48.18024 \\
4 & 1479.657 & 66.24907 & 33.75093 \\
5 & 1812.752 & 75.64935 & 24.35065 \\
6 & 2141.035 & 81.76948 & 18.23052 \\
7 & 2455.329 & 85.83483 & 14.16517 \\
8 & 2749.311 & 88.60043 & 11.39957 \\
9 & 3018.957 & 90.52269 & 9.477310 \\
10 & 3262.034 & 91.88161 & 8.118391 \\
\hline
\end{tabular}

Source: E-views program dependent on appendix (1).

\subsection{Johnson Co-Integration Test}

Co-integration aims to test the equilibrium relationship in the long term. This test requires a degree of stability and integration of variables at the same rank. Given the similarity among variables' stability at the same degree in Table (4), co-integration can be conducted in the long run. According to Johnson's style in Table (5), at least one integral relationship exists between the two variables at $5 \%$ level.

Table 10. Johnson co-integration test

\begin{tabular}{cllll}
\hline & $\begin{array}{l}\text { Trace } \\
\text { Statistic }\end{array}$ & 0.05 & Prob.** \\
Eigenvalue & & Critical Value & Hypothesized \\
& & & No. of CE(s) \\
\hline 0.901834 & 0.901834 & 20.26184 & 0.0000 & None * \\
0.291406 & 0.291406 & 9.164546 & 0.1758 & At most 1 \\
\hline
\end{tabular}

Source: E-views program dependent on appendix (1). 


\section{Conclusion and Policy Implications}

The results of the unit root test showed that the study's variables were stable at the same degree where the two variables, namely, workers' remittances and M2 are stable in the second difference. The results of the vector autoregression model indicate a positive effect of workers 'remittances on M2 and a negative effect of M2 on workers' remittances, which lacks statistical significance.

The results of the causality test reveal that workers' remittances affect M2, but not vice versa. In addition, the response functions reveal that random shocks of workers' remittances exhibit a positive effect on the M2 volume, while M2 shocks slightly and negatively affect workers' remittances during the study period.

The immediate results of the analysis of variance uncover the relative importance of workers' remittances in the interpretation of M2 in the current period and through time movements, as well as the low interpretive capacity of the M2 in workers' remittances simultaneously.

Through the co-integration between the two variables, at least one integration relationship is found between the two variables, namely, workers' remittances and M2.

\section{Recommendations}

Based on the causal analysis, workers' remittances affect money to be offered. Thus, workers' remittances affect M2 and affect the economic activity in the country. Therefore, workers' remittances must be considered. Also, based on the results of the response functions, the impact of workers' remittances on the M2 is positive. Therefore, this study recommends that policy makers must focus on and take workers' remittance into account when monetary policy decisions developed.

The results of the analysis of the variance components showed the explanatory importance of workers' remittances in the interpretation of M2. In addition, these findings motivate us to provide increasing attention toward workers' remittances and increase them by cooperating with countries that demand for Jordanian labor, particularly the Gulf States. Additional standardized studies that rely on dynamic analysis to build accurate statistical models of workers' remittances and their impact on economic activities in Jordan should be conducted. The central bank must be use non-conventional tools to absorb liquidity and reduce the impact of workers' remittances on inflation, such as Islamic Sukuk.

\section{References}

Aliaa, N. K. (2015). Migration Remittances Inflows and Macroeconomic Shocks: The Case of Egypt. International Journal of Economics and Financial Issues, 5(4), 1001-1010.

Deodat, E. A., \& Christian, R., K. (2008). Remittances, Exchange Rate, and Monetary Policy in Ghana. West African Journal of Monetary and Economic Integration, 8(2), 1-30.

Friday, O. (2019). Remittance and Economic Growth Nexus in Nigeria: Does Financial Sector Development Play a Critical Role? International Journal of Management, Economics and Social Sciences, 8(2), 116-135.

The International Fund for Agricultural Development. (2015). The Use of Remittances and Financial Inclusion, A report prepared by the International Fund for Agricultural Development and the World Bank Group to the G20 Global Partnership for Financial Inclusion. Retrieved from https://www.ifad.org/documents/38714170/40187309/gpfi.pdf/58ce7a06-7ec0-42e8-82dc-c069227edb79

Javed, I., Quaid-i-Azam, I., Misbah, N., \& Mansehra, A. J. (2013). The Nexus between Foreign Remittances and Inflation: Evidence from Pakistan. Pakistan Journal of Social Sciences (PJSS), 33(2), 331-342.

Jennifer, I., Rani, D., \& Judith, V. D. (2005). A Transversal Study: Preparing a Money Transfer Strategy: Guidance for Pro-Poor Financial Services Providers, No. 10, CGAP.

Junaid, A., Khalid, Z., \& Iqtidar, A. S. (2011). An empirical analysis of remittances-growth nexus in Pakistan using bounds testing approach. Journal of Economics and International Finance, 3(3), 176-186.

Katsushi, S., Imai, B. M., \& Fabrizio, B. (2017). Remittances, growth and poverty reduction in Asia. 15 IFAD Research Series (pp. 1-47).

Krep, A. H. (2018). The use of the vectore Autoregression (to study the relationship between the volume of public spending and population growth in Sudan for the period 1960-2015). Journal of Economic and Administrative Sciences, 19(2), 116-136.

Mahedi, M. (2014). Workers' Remittance Inflow, Financial Development and Economic Growth: A Study on Bangladesh. International Journal of Economics and Finance, 1(6), 247-267. 
Majid, T. (2012). The Impact of Workers' Remittances on Macro Indicators: The case of the Gulf Cooperation Council. Topics in Middle Eastern and African Economies, 14, 49-73. Retrieved from https://pdfs.semanticscholar.org/c1e1039

Mina, M. (2013). Maximize the development impact of remittances, Division on International Trade in Goods and Services, and Commodities.

Mohamed, S. A. Z. (2019). The response of remittances inflows to asymmetric oil price shocks in Egypt. Review of Economics and Political Science, 3(2). Retrieved from http://www.emeraldinsight.com/2631-3561.htm

Naoyuki, Y., Farhad,T. H., \& Miyu, O. (2019). Determinates Of International Remittance Inflows In Middle Come Countries In Asia The Pacific. ADBI Working Paper Series (pp. 1-17).

Nawal, B. A. (2011). Islamic Sukuk and its role in the development of the Islamic financial market Experience of the international Islamic financial market.

Niaz, H. G., \& Mohd, Z. A. K. (2017). The Role of Remittances in Stabilizing Demand for Money in Pakistan: co-integration Analysis. Economic Analysis, 16(213), 45-65.

Ripon, R., \& Md. Mokhlesur, R. (2014). An Empirical Analysis of Remittance - Inflation Relationship in Bangladesh: Post-Floating Exchange Rate Scenario. Retrieved from https://mpra.ub.uni-muenchen.de/55190/

Suwastika, N., Atishwar, P., \& Anand, C. (2017). A Johansen Cointegration Test for the Relationship between Remittances and Economic Growth of Japan. Modern Applied Science, 11(10), 137-151. Retrieved from https://core.ac.uk/download/pdf/86579235.pdf

Akinbobola, T. O. (2012). The dynamics of money supply, exchange rate and inflation in Nigeria. Journal of Applied Finance \& Banking, 2(4), 117-141.

Uzoh, A. B., Nwachukwu, A. C., \& Uzoma, K. (2019). International Remittances, Financial Deepening and Economic Growth Nigeria (1985-2016). Global Journal of Applied, Management and Social Sciences (GOJAMSS), 17, 15-31.

Appendix (1): data of variables during the period (2000-2018)

\begin{tabular}{lll}
\hline Years & $\mathrm{m} 2$ & RMT \\
\hline 2000 & 7434.7 & 1177.3 \\
2001 & 7866.1 & 1283.3 \\
2002 & 8419.1 & 1362.3 \\
2003 & 9465.7 & 1404.5 \\
2004 & 10571.4 & 1459.6 \\
2005 & 12364 & 1544.8 \\
2006 & 14109.7 & 1782.7 \\
2007 & 15606.8 & 2122.5 \\
2008 & 18304.2 & 2242 \\
2009 & 20013.3 & 2214.2 \\
2010 & 22306.7 & 2247.3 \\
2011 & 24118.9 & 2152.1 \\
2012 & 24945.1 & 2229.8 \\
2013 & 27363.4 & 2327.7 \\
2014 & 29240.4 & 2388 \\
2015 & 31605.5 & 2423.3 \\
2016 & 32876.2 & 2365.7 \\
2017 & 32957.6 & 2371.9 \\
2018 & 33359.3 & 2345.7 \\
\hline
\end{tabular}

Source: Central Bank of Jordan (http://statisticaldb.cbj.gov.jo/index?action=level4\#). 


\section{Copyrights}

Copyright for this article is retained by the author(s), with first publication rights granted to the journal.

This is an open-access article distributed under the terms and conditions of the Creative Commons Attribution license (http://creativecommons.org/licenses/by/4.0/). 